\title{
What do Polish interventional cardiologists know about indications and qualification for recanalisation of chronic total coronary artery occlusions?
}

\author{
Krzysztof L. Bryniarski ${ }^{1}$, Michał Zabojszcz², Grzegorz Dębski², Jakub Marchewka ${ }^{3}$, Jacek Legutko4, \\ Piotr Jankowski ${ }^{5}$, Zbigniew Siudak ${ }^{4}$, Krzysztof Żmudka ${ }^{1}$, Dariusz Dudek ${ }^{4}$, Leszek Bryniarski ${ }^{5}$ \\ 'Department of Interventional Cardiology, John Paul II Hospital, Jagiellonian University, Medical College, Krakow, Poland \\ 2Department of Cardiology, J. Dietl Hospital, Krakow, Poland \\ ${ }^{3}$ Department of Orthopaedics and Trauma Surgery, $5^{\text {th }}$ Military Hospital, Krakow, Poland \\ 4Department of Cardiology and Cardiovascular Interventions, Jagiellonian University, Medical College, University Hospital, Krakow, Poland \\ ${ }^{5} 1^{\text {st }}$ Department of Cardiology, Interventional Electrocardiology, and Arterial Hypertension, Jagiellonian University, Medical College, \\ University Hospital, Krakow, Poland
}

\begin{abstract}
Background: Chronic total occlusions (CTO) are diagnosed in about 20\% of patients with significant coronary artery disease. A disproportion between the high prevalence of CTOs and low rate of invasive treatment still exists. Technical difficulties, clinical uncertainties whether patients benefit from recanalisation, and a lack of knowledge of CTO may be responsible for this fact. Aim: To assess the knowledge of coronary arteries CTO among Polish interventional cardiologists.

Methods: A self-designed questionnaire was used during two major Polish invasive cardiology workshops held in 2014.

Results: The study included 113 physicians, mostly cardiologists certified as independent operators. Average self-declared efficacy of CTO recanalisation was $63.5 \%$. Most of the respondents agreed that the operator involved in the CTO recanalisation program should perform at least 30-50 procedures per year. Only 67\% stated that before CTO revascularisation the evaluation of myocardial viability should be performed with dobutamine stress echocardiography as a preferred test. One third of the physicians agreed that CTO percutaneous coronary intervention (PCI) should not be performed directly after diagnostic angiography, and 51.5\% believed that in patients with multi-vessel coronary artery disease PCI of CTO should be performed first. Multi-slice spiral computed tomography during the qualification and planning of the CTO revascularisation, in the opinion of $91 \%$ of the responders, should not be used before each procedure but could be useful in selected cases.

Conclusions: Polish interventional cardiologists remains in compliance with current opinions about recanalisation of chronic coronary artery occlusions and the consensus of the EuroCTO Club, but there is still an unceasing need for further education and promotion of knowledge about CTOs.
\end{abstract}

Key words: chronic total occlusions, percutaneous interventions, physicians' knowledge

Kardiol Pol 2015; 73, 9: 722-729

\section{INTRODUCTION}

Chronic total occlusion (CTO) of the coronary artery is currently defined as the presence of thrombolysis in myocardial infarction (TIMI) 0 flow within the occluded segment (i.e. com- plete discontinuation of the coronary lumen in angiography) with an estimated occlusion duration of $\geq$ three months [1]. The reported prevalence of CTOs in patients with clinically significant coronary artery disease (CAD) varies widely, from

\section{Address for correspondence:}

Prof. Leszek Bryniarski, MD, PhD, FESC, $1^{\text {st }}$ Department of Cardiology, Interventional Electrocardiology, and Arterial Hypertension, University Hospital, Jagiellonian University Medical College, ul. Kopernika 17, 31-501 Kraków, Poland, tel: +48 1242473 00, fax: +48 12424 73 20, e-mail: I_bryniarski@poczta.fm Received: 17.12.2014 Accepted: 09.03.2015 Available as AoP: 28.04.2015

Copyright (C) Polskie Towarzystwo Kardiologiczne 
$16 \%$ to $50 \%$, but is generally about $20 \%$ in large registries [2]. In a report from the Canadian multicentre CTO registry, a CTO was observed in $14.7 \%$ of patients without previous coronary artery bypass surgery (CABG) undergoing coronary angiography, and in $18.4 \%$ of patients with clinically significant CAD [3]. In this registry, the majority of patients were treated medically $(64 \%)$ or were referred for CABG surgery (26\%) — only $10 \%$ were referred for percutaneous coronary intervention $(\mathrm{PCl})$ of the occluded vessel. The disproportion between high prevalence of CTOs and low rate of invasive treatment emphasises the higher technical difficulty and perceived risk of complications compared with non-invasive treatment, as well as the clinical uncertainties with regard to which patients benefit from CTO revascularisation [4]. In specialised centres using modern devices and new techniques the efficacy of revascularisation procedures of CTO has improved and reached up to $90 \%$, even when attempting more complex CTOs than ten years ago [5].

According to unpublished data of the Association of Cardiovascular Interventions of the Polish Cardiac Society (ACVI) during the first six months of 2014, 601 procedures of CTO were performed in Poland, with a $54 \%$ success rate (50\% patients with TIMI 3 flow after procedure and $4 \%$ with TIMI 2). As we described previously, in 2010 the level of knowledge regarding chronic total occlusions of coronary arteries was not sufficient [6]. Since this time the new consensus of the EuroCTO Club was published and CTO has been one of the most important topics during national and international cardiology congresses [4].

\section{METHODS}

The aim of our study was to evaluate knowledge about CTO among Polish interventional cardiologists.

Our study was conducted among cardiologists and physicians interested in the topic of CTO. For that a self-written questionnaire (in Polish) was used. The majority of the questions were closed question with two to six answers to choose from, most with multiple choices. The first questions characterised the participants of the study, and the next concerned knowledge about CTO: recommended diagnostics methods, the need to evaluate ischaemia and viability before revascularisation, and preferred treatment methods including procedural aspects of retrograde recanalisation. The complete set of questions is shown in Figure 1.

The study was conducted during the XIV Workshops New Frontiers in Interventional Cardiology (NFIC) in Krakow on 27-30 November 2013 and at the XVIII Warsaw Course on Cardiovascular Interventions (WCCl), which was held on 9-11 April 2014.

\section{Statistical analysis}

The comparison of numbers and percentages of cases with regards to the whole analysed group is presented. To assess the differences in the nominal variables non-parametric $\left(\chi^{2}\right)$ Pearson's test, Yates' $\chi^{2}$, or Fisher's exact test was applied (depending on the number of subjects in subgroups). In order to assess the strength of the relations between variables Spearman's correlation test was used. Results with $p$ value $<0.05$ were considered significant. Statistical analysis was carried out with a use of STATISTICA 8 PL software (StatSoft Inc.).

\section{RESULTS}

In our study 113 physicians completed the questionnaire. The average length of work experience was 13 years (from one to 32 years, median 12 years), 34\% of responders worked for more than 15 years, $33 \%$ of physicians had a medical doctor title, and $8 \%$ had a professor title. Most of the responders had a specialisation in cardiology (58\%) or were in the process of that specialisation (33\%). Most common place of work was a non-academic cardiology ward with catheterisation laboratory, and $27 \%$ worked in an academic cardiology clinic with catheterisation laboratory. $73 \%$ of responders identified themselves as independent operators.

The declared number of diagnostic coronary angiographies performed for the last year was 340 on average (from 0 to 1000, median 300). The declared volume of $\mathrm{PCI}$ performed during the preceding year was 177 on average (from 0 to 800, median 180), including 23 CTO interventions (from 0 to 70 , median 20). 29\% of persons claimed to have performed more than 30 CTO interventions during one year, and only $5 \%$ claimed to have carried out more than 50 CTO interventions per year. Not surprisingly, the number of CTO procedures increases with the length of work experience ( $p=0.03572$; Fig. 2$)$ as well as with average number of diagnostic coronary angiographies $(p<0.01)$ and PCls performed per year $(p<0.000001)$. Also, CTO recanalisation is more often carried out by certified cardiologists than by cardiologists in training. No difference was found in the number of performed CTO procedures between academic and non-academic centres of interventional cardiology.

The average self-declared efficacy of $\mathrm{PCl}$ in CTO was $63.5 \%$ (from $20 \%$ to $100 \%$, median $60 \%$; the physician who declared an efficacy of $100 \%$ performed only one CTO procedure during the preceding year). Operators performing more than $30 \mathrm{CTO}$ interventions per year rated their efficacy at $70 \%$ (from $40 \%$ to $90 \%$, median $75 \%$ ). Cardiologists who perform more than 50 CTO interventions per year evaluated their efficacy at $68 \%$. The number of CTO procedures performed annually was the only factor influencing the declared effectiveness of CTO recanalisation ( $p=0.005$; Fig. 3).

Most of the respondents (81\%) agreed that interventional cardiologists involved in CTO recanalisation program should perform at least 30-50 procedures per year. Among the analysed subgroups only persons who did not identify themselves as independent operators were more likely to disagree with that statement, but the available data does not allow us to 
We would be grateful if you spend several minutes filling out the questionnaire. We will appreciate all additional comments.

Country of residence:

Work experience (years):

Academic title:

1) Specialisation:
a) without specialisation
d) internal medicine specialist
b) during specialisation - internal medicine
e) cardiology specialist

c) during specialisation — cardiology

2) Place of work (more than one answer possible):
a) cardiology department with cath lab
d) public hospital
b) cardiology department without cath lab
e) academic hospital
c) private hospital
f) outpatient clinic

3) Experience in invasive cardiology:
a) first operator
b) diagnostician

4) Number of coronarographies performed during last year:

5) Number of $\mathrm{PCl}$ performed last during year:

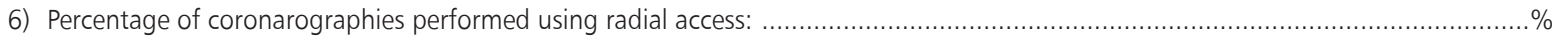

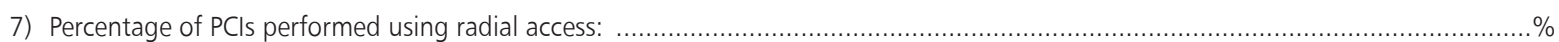

8) Your own experience when comparing radial access to femoral access (more than one answer possible):
a) longer time of procedure
d) more frequent occlusions in punctured vessel
b) more complications
e) frequent switch to femoral access

c) bigger amount of radiation

9) Which access site, in in your opinion, is better for the patient?

a) radial

b) femoral

10) Do you choose the access site with regard to quality of life? YES / NO

11) Do you talk with the patient about access site options? YES / NO

12) Have you ever used any of quality of life questionnaires? YES / NO

If yes, which one:

13) Number of $\mathrm{PCl}$ in $\mathrm{CTO}$ performed last year:

14) Efficacy of PCI CTO:

\begin{tabular}{|c|c|c|c|}
\hline Question & Agree & Disagree & Different answer \\
\hline \multicolumn{4}{|l|}{ A viability test should be required in all patients } \\
\hline \multicolumn{4}{|l|}{ Is not required in patients with no prior Q-MI } \\
\hline \multicolumn{4}{|l|}{ What is your preferred viability test? } \\
\hline \multicolumn{4}{|l|}{ CTO-PCl should not be done ad hoc } \\
\hline \multicolumn{4}{|l|}{ In MVD disease CTO-artery should always be attempted first } \\
\hline \multicolumn{4}{|l|}{ СТO operators should do at least 30-50 СТO cases annually } \\
\hline CABG results are: & \multicolumn{3}{|l|}{$\begin{array}{l}\text { a) better } \\
\text { b) similar } \\
\text { c) worse than } \mathrm{PCl}\end{array}$} \\
\hline \multicolumn{4}{|l|}{ ACT should be measured } \\
\hline If yes, ACT level should be kept at & $\begin{array}{l}\text { a) }>200 \\
\text { b) }>250 \\
\text { c) }>300\end{array}$ & & \\
\hline \multicolumn{4}{|l|}{ MSCT used preferably for all cases } \\
\hline \multicolumn{4}{|l|}{ MSCT used for selected cases (give an estimated \%) } \\
\hline MSCT used only before $2^{\text {nd }}$ (antegrade) attempt & & & \\
\hline
\end{tabular}

Figure 1. The questionnaire used in the study; $A C T$ - activated clotting time; CABG — coronary artery bypass graft surgery; CTO - chronic total occlusions; MI - myocardial infarction; MSCT — multi-slice spiral computed tomography; MVD — multi-vessel disease; $\mathrm{PCl}$ - percutaneous coronary intervention 


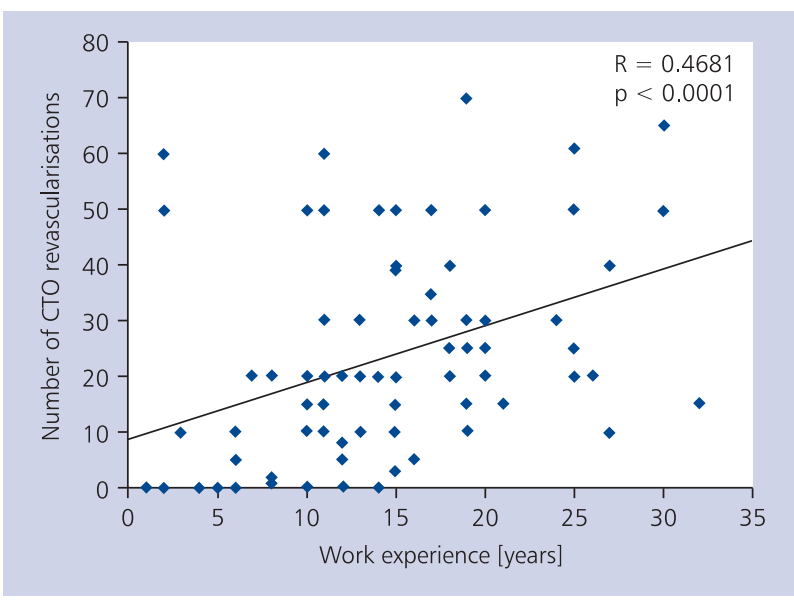

Figure 2. Number of percutaneous coronary interventions in chronic total occlusions (CTO) performed annually, according to the length of work experience

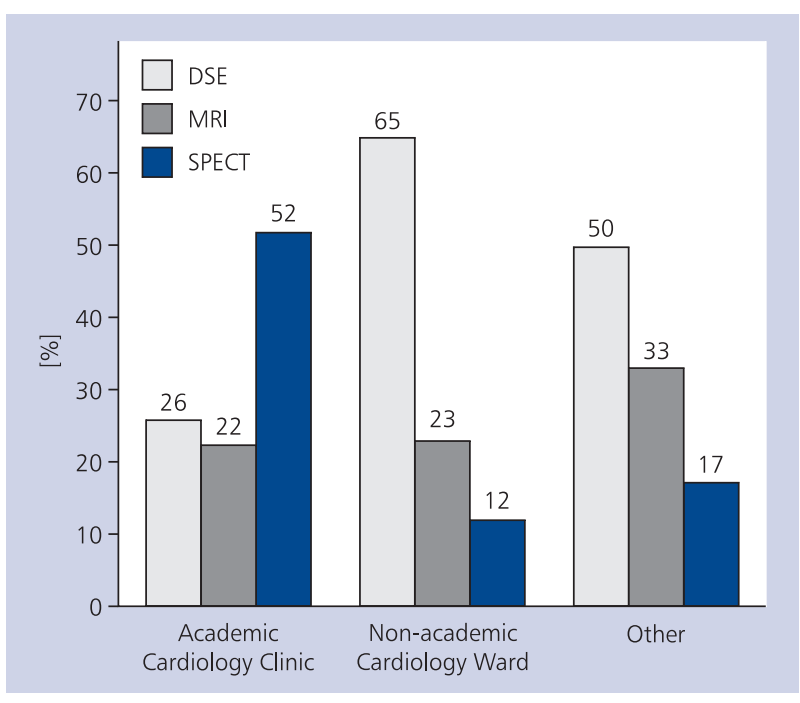

Figure 4. Preferred test to access myocardial viability according to place of work; DSE - dobutamine stress echocardiography; $\mathrm{MRI}$ - magnetic resonance imaging; SPECT — single-photon emission computed tomography

conclude whether they consider this number to be too small or too large.

Only $67 \%$ of the participants of our study stated that before revascularisation of coronary artery CTO the evaluation of the myocardial viability of the akinetic region of the left ventricle should be performed. $22 \%$ of physicians agreed that it is necessary to evaluate viability of myocardium in patients with no Q wave in electrocardiogram (ECG). In both questions we found no relationship between those responses and length of work experience, academic title and possession of specialisation, place of work, experience as independent operator, or the number of performed CTO procedures.

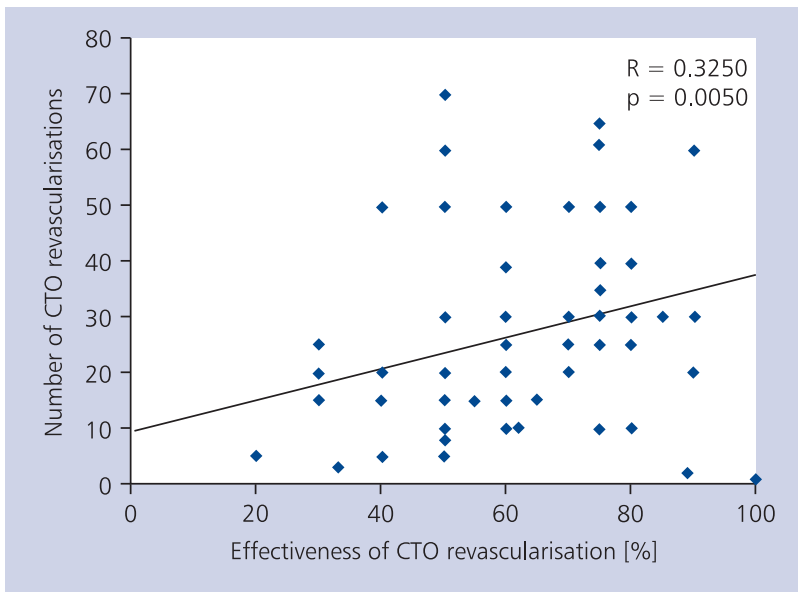

Figure 3. Declared effectiveness of chronic total occlusions (CTO) recanalisation, according to the annual number of performed of CTO procedures

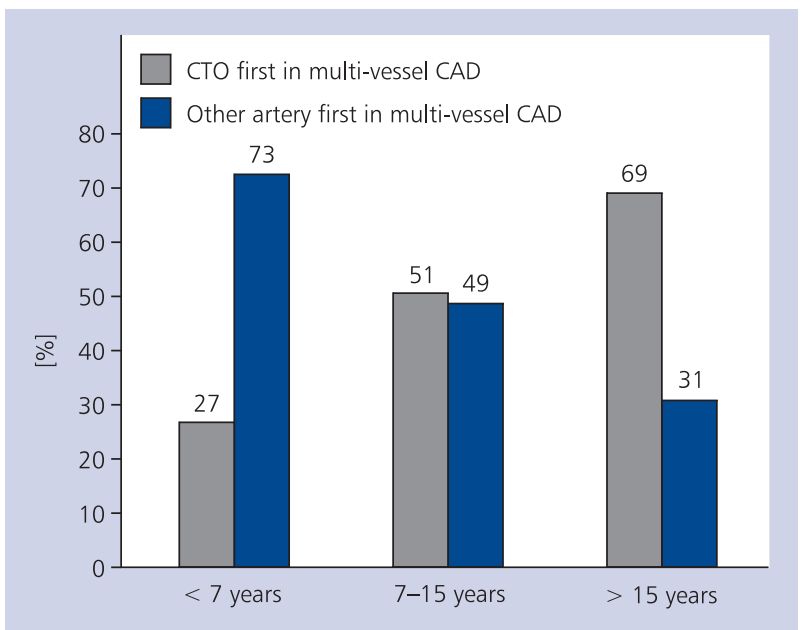

Figure 5. Sequence of chronic total occlusions (CTO) recanalisation in multi-vessel coronary artery disease (CAD), depending on responder's work experience

As a preferred test to assess myocardium viability $54 \%$ of physicians indicated dobutamine stress echocardiography, 23.5\% magnetic resonance imaging (MRI) scan, and 21\% single-photon emission computed tomography (SPECT). Stress echocardiography was most frequently indicated by those who worked in non-academic cardiology wards and other places (like outpatients clinics), while SPECT was preferred by cardiologist employed in academic cardiology clinics $(p=0.00603$, Fig. 4). Also, operators who performed more than 50 CTOs per year preferred MRI and SPECT rather than stress echocardiography; probably due to the small size of this group the relationship did not reach statistical significance $(p=0.05712)$.

Most of the physicians $(78 \%)$ agreed with the statement that CTO procedures should not be performed directly after 
diagnostic coronary angiography, and that ad hoc recanalisation should be performed immediately after diagnostic coronary angiography only in selected cases. This opinion does not depend on length of work experience, academic title, possession of specialisation, place of work, or experience as independent operator. Only operators who perform more than 50 CTOs often argued that CTOs could be performed ad hoc after diagnostic coronary angiography.

Only $51.5 \%$ of physicians believed that in patients with multi-vessel CAD angioplasty of occluded artery should be performed first. That statement was upheld more often by cardiologists, individuals with longer work experience (Fig. 5), independent operators, and persons performing more CTO procedures per year.

When evaluating the efficacy of $\mathrm{PCI}$ with regard to $\mathrm{CABG}$, $29 \%$ of physicians believed that the results of CABG were better, $47 \%$ that they were the same, and $13 \%$ that they were worse than $\mathrm{PCl} .11 \%$ of the participants of our survey could not answer that question, stating that they did not know of the relevant studies or that there were too many factors affecting results, so it is impossible to compare these methods of treatment. There are no identifiable characteristics affecting the conviction of superiority of either of these treatment modalities.

When evaluating the usefulness of multi-slice spiral computed tomography (MSCT) during the qualification and planning of CTO revascularisation, $91 \%$ of responders stated that this test should not be used before each procedure and that it could be useful in selected cases. Physicians assessed that MSCT should be used before $27 \%$ of PCls in CTO. Simultaneously, $24 \%$ of responders stated that MSCT should be used only before a second attempt of recanalisation using the antegrade technique. The necessity of performing MSCT before each procedure was more often indicated by less experienced participants of our survey (cardiologist in training and physicians who were not independent operators) but also by the cardiologist performing the largest number of CTO procedures per year.

\section{DISCUSSION}

The presented study is the first attempt to assess the knowledge about chronic total occlusions of the coronary arteries among Polish interventional cardiologists. In our previous study we were able to present the knowledge of this topic among Polish physicians with an interest only in cardiology [6]. In our opinion the survey conducted during two major Polish interventional cardiology workshops ensures representativeness of the study sample. However, we would like to emphasise that the results were obtained on the basis of the operators subjective estimates and thus might be different when analysing controlled database. The mean working time of surveyed physicians was 13 years, and the majority had passed a cardiology exam and worked in the departments of cardiology with catheterisation laboratory. More than two thirds were certified as independent operators.
The mean declared number of PCls performed in the last year was 177, including 23 procedures of CTO recanalisation. Only one third $(27 \%)$ declared more than $30 \mathrm{PCls}$ of CTO performed yearly, and the minority (4\%) performed more than 50 procedures during a year. Those numbers reflect also the mean efficacy of CTO procedures, declared as $63.5 \%$. This is in accordance with the recent data of the Association of $\mathrm{ACVI}$, specifying an efficacy of $54 \%$. Even experienced centres and operators, such as those participating in the SYNTAX trial, achieved a success rates of less than $60 \%$ [7]. The 2010 guidelines of the European Society of Cardiology for myocardial revascularisation recommend that CTO revascularisation should be restricted to operators with a success rate exceeding 80\% [8]. According to the EuroCTO Club consensus, training in such complex procedures like CTO should come second to the full understanding and exposure to $\mathrm{PCI}$ in general, but, since the operations are often very complex, a sufficient number of procedures should be required before beginning to treat CTOs, as well as a minimal annual number to maintain and further develop the skills [4]. The minimal number of procedures to drive the success rate above $80 \%$ proposed in the EuroCTO Club consensus is an annual case load of $>50$ procedures of CTO $\mathrm{PCl}$, which can maintain the competency $[4,8]$. All interventional trainees should have the theoretical knowledge for appropriate patient and lesion selection and practical experience to avoid the most common mistakes in CTO recanalisation [4]. Sufficient training to work as an independent operator for most angioplasty procedures does not automatically translate into an ability to approach any CTO [4].

In our study we confirmed the observation that the number of procedures translates into the success rate; the mean declared success rate of operators performing more than 50 procedures per year was $68 \%$. For proper qualification of patients we propose the use of the Multicentre CTO Registry of Japan (J-CTO) score. This is a simple method to assess the complexity and difficulty of CTOs proposed by Morino et al. [9]. The score is determined by assigning one point to each of five variables (previously failed lesion, blunt proximal cap, severe CTO calcification, severe vessel tortuosity, and occlusion length $\geq 20 \mathrm{~mm}$ ), thereby allowing patient classification into four groups: easy (J-CTO score $=0$ ), intermediate (score $=1$ ), difficult (score $=2$ ), and very difficult (score $\geq 3$ ). From our experience, an operator not dedicated to CTO is competent enough to try to open easy or intermediate CTOs (graded from 0 to 1 ). If J-CTO score is 2 or more the patient should be referred to a centre specialising in CTO treatment with dedicated and experienced operators.

The goal of revascularisation in CTOs is to improve symptoms and/or prognosis [10]. In several studies it has been documented that successful recanalisation leads to improvement in physical activity and quality of life, reduction of angina symptoms, normalisation of functional tests, improvement of 
left ventricular function, and avoidance of CABG $[4,10,11]$. Data from retrospective studies, prospective registries, and recent meta-analyses shows that patients with a successful CTO PCI have better chances of survival and reduced need for $\mathrm{CABG}$ in comparison to patients in whom the procedure was unsuccessful $[4,12,13]$. Patients with untreated CTOs have increased mortality or complication rates in case of future acute events [4, 14-17]. Fundamental to qualification to the CTO procedure is ischaemia and/or viability confirmation of myocardium in occluded artery territory [4]. Despite this, as many as $33 \%$ of our respondents did not see the need to prove the viability of akinetic myocardium before the recanalisation procedure.

It has been reported that the absence of the Q-waves in a 12-lead ECG could predict the recovery of regional wall motion after the CTO PCl; nevertheless, only $22 \%$ answered that in such situation there is a need to prove the viability of akinetic region of myocardium [18]. The preferred test for viability assessment in our study was dobutamine stress echocardiography; we can presume that the availability and costs place this test above MRI.

Ad hoc CTO $\mathrm{PCl}$ is not recommended by EuroCTO Club consensus and $78 \%$ of cardiologists agree with that, but, surprisingly, experienced operators often argue that CTO recanalisation could be performed ad hoc after diagnostic coronary angiography. It is still a matter of discussion as to which artery to tackle first in the presence of multi-vessel disease. The decision should be based on the importance of the occluded vessel: if the vessel and the amount of viable myocardium is important, the CTO should be approached first, whereas in cases with poor contralateral flow or an intended retrograde approach a stenosis in the contralateral vessel may need to be treated first. Moreover, inverted collateral flow through the reanalysed CTO may protect the myocardium at risk during high-risk complex lesions in the collateral donor vessel. It is important that each case should be considered individually [4]. Those doubts are reflected by the answer to the simple question of which artery should be treated first in multi-vessel disease; without any additional information $51.5 \%$ of physicians decided to treat the occluded vessel first.

The question regarding the results of $\mathrm{PCl}$ compared to CABG was a little provocative; there are many trials concerning this topic, and new trials are planned [10]. Recently the SYNTAX trial showed that CABG remains the standard of care for patients with three-vessel or left main CAD, since the use of $\mathrm{CABG}$, as compared with $\mathrm{PCl}$, resulted in lower rates of the combined end point of major adverse cardiac or cerebrovascular events at one year [19]. In our survey one third of responders believed that the surgery is better, half evaluated these two modalities similarly, 13\% considered PCI more advantageous, and $11 \%$ surprisingly did not know of such studies.

The EuroCTO Club consensus stated that MSCT cannot be recommended for routine preprocedural imaging for CTO
$\mathrm{PCl}$, and this is consistent with $91 \%$ of the answers in our questionnaire [4]. The consensus also states that this tool can be recommended for complex CTO lesions, with an expected success rate $<50 \%$, and in cases of repeat procedures after initial CTO recanalisation failure [4]. This may change in near future due to more data confirming the usefulness of this method in planning the procedures and achieving better results [20].

\section{CONCLUSIONS}

Based on our survey, in most cases, Polish interventional cardiologists remains in compliance with current opinions about recanalisation of chronic coronary artery occlusions and the consensus of the EuroCTO Club. There is still an unceasing need for further education and promotion of knowledge about CTOs not only amongst younger and less experienced colleagues, but also among cardiologists who in their own opinion are experienced operators.

\section{Conflict of interest: none declared}

\section{References}

1. Di Mario C, Werner GS, Sianos G et al. European perspective in the recanalisation of Chronic Total Occlusions (CTO): consensus document from the EuroCTO Club. EuroIntervention, 2007; 3: 30-43.

2. Hoebers LP, Claessen BE, Dangas GD et al. Contemporary oveview and clinical perspectives of chronic total occlusions. Nat Rev Cardiol, 2014; 11: 458-469. doi: 10.1038/ncardio.2014.74.

3. Fefer P, Knudtson ML, Cheema AN et al. Current perspectives on coronary chronic total occlusions: the Canadian Multicenter Chronic Total Occlusions Registry. J Am Coll Cardiol, 2012; 59: 991-997. doi: 10.1016/j.jacc.2011.12.007.

4. Sianos G, Werner GS, Galassi AR et al. Recanalisation of chronic total coronary occlusions: 2012 consensus document from the EuroCTO Club. Eurointervention, 2012; 15: 139-145. doi: 10.4244/EIJV8I1A21.

5. Syrseloudis D, Secco GG, Barrero A et al. Increase in J-CTO lesion complexity score explains the disparity between recanalisation successand evolution of chronic total occlusion strategies: insights from a single-center 10-year experience. Heart, 2013; 99: 474-479. doi: 10.1136/heartjnl-2012-303205.

6. Bryniarski L, Zabojszcz M, Bryniarski K, Terlecki M. Knowledge about chronic total coronary artery occlusions among Polish physicians. Post Kardiol Interw, 2010; 6: 66-70.

7. Faroq V, Serruys PW, Garcia-Garcia HM et al. The negative impact of incomplete angiographic revascularization on clinical outcomes and its association with total occlusions: the SYNTAX (Synergy Between Percutaneous Coronary Intervention with Taxus and Cardiac Surgery) trial. J am Coll Cardiol, 2013; 61: 282-294. doi: 10.1016/j.jacc.2012.10.017.

8. Galassi AR, Tomasello SD, Reifart N et al. In-hospital outcomes of percutaneous coronary intervention in patients with chronic total occlusion: insights from the ERCTO (European Registry of Chronic Total Occlusion) registry. Eurointervention, 2011; 7: 472-479. doi: 10.4244/EIJV7I4A77.

9. Morino Y, Abe M, Morimoto T for the J-CTO Registry Investigators. Predicting successful wire crossing through chronic total occlusion of native coronary vessels within 30 minutes: The J-CTO (Multicenter CTO Registry in Japan) score as a difficulty grading and time assessment tool. J Am Coll Cardiol Interv, 2011; 4: 213-221. doi: 10.1016/j.jcin.2010.09.024. 
10. Wijns W, Kolh P, Danchin N, et al. Guidelines on myocardial revascularization: The Task Force on Myocardial Revascularization of the European Society of Cardiology (ESC) and the European Association for Cardio-Thoracic Surgery (EACTS). Eur Heart J, 2010; 31: 2501-2555. doi: 10.1093/eurheartj/ehq277.

11. Borgia F, Viceconte N, Ali O et al. Improved cardiac survival, freedom from MACE and angina-related quality of life after successful percutaeous recanalization of coronary artery chronic total occlusions. Int J Cardiol, 2012; 161: 31-38. doi: 10.1016/j. ijcard.2011.04.023.

12. Khan MF, Wendel CS, Thai HM, Movahed MR. Effects of percutaneous revascularization of chronic total occlusion on clinical outcomes: a meta-analysis comparing successful versus failed percutaeous intervention for chronic total occlusion. Catheter Cardiovasc Interv, 2013; 82: 95-107. doi: 10.1002/ccd.24863.

13. Pancholy SB, Boruah P, Ahmed I et al. Meta-analysis of eddect on mortality of percutaeous recanalization of coronary chronic total occlusions using a stent-based strategy. Am J Cardiol, 2013; 111: 521-525. doi: 10.1016/j.amjcard.2012.10.034.

14. De Felice F, Fiorilli F, Parma A et al. Effect of multivessel coronary artery disease with or without a concomitant chronic total occlusion on 1-year survival in patients treated with rescue angioplasty. J Invasive Cardiol, 2013; 25: 64-68.

15. Hoebers LP, Vis MM, Claessen BE et al. The impact of multivessel disease with and without a co-existing chronic total occlusion on short- and long-term mortality in ST-elevation myocardial patients with and without cardiogenic shock. Eur J Heart Fail, 2013; 15: 425-432. doi: 10.1093/eurjhf/hfs182.

16. Gierlotka M, Tajstra M, Gąsior M et al. Impact of chronic total occlusion artery on 12-month mortality in patients with non-ST-segment elevation myocardial infarction treated by percutaneous coronary intervention (from the PL-ACS Registry). Int JCardiol, 2013; 168: 250-254. doi: 10.1016/j.ijcard.2012.09.086.

17. Yang ZK, Zhang RY, Hu J et al. Impact of successful staged revascularization of chronic total occlusion in the non-infarct-related artery on long-term outcome in patients with acute ST-segment elevation myocardial infarction. Int J Cardiol, 2013; 165: 76-79. doi: 10.1016/j.ijcard.2011.07.074.

18. Surber R, Schwarz G, Figulla HR, Werner GS. Resting 12-lead electrocardiogram as a reliable predictor of functional recovery after recanalization of chronic total coronary occlusions. Clin Cardiol, 2005; 28: 293-297.

19. Serruys PW, Morice MC, Kappetein AP et al. Percutaneous coronary intervention versus coronary-artery bypass grafting for severe coronary artery disease. N Engl J Med, 2009; 360: 961-972. doi: 10.1056/NEJMoa0804626.

20. Rolf A, Werner GS, Schuchback A et al. Preprocedural coronary CT angiography significantly improves success rate of PCI for chronic total occlusion. Int J Cardiovasc Imaging, 2013; 29: 1819-1827. doi: 10.1007/s10554-013-0258-y.

\title{
Co polscy kardiolodzy interwencyjni wiedzą o wskazaniach i kwalifikacji do zabiegów udrażniania przewlekłych okluzji tętnic wieńcowych?
}

\author{
Krzysztof L. Bryniarski ${ }^{1}$, Michał Zabojszcz², Grzegorz Dębski², Jakub Marchewka', Jacek Legutko4, \\ Piotr Jankowski ${ }^{5}$, Zbigniew Siudak ${ }^{4}$, Krzysztof Żmudka ${ }^{1}$, Dariusz Dudek ${ }^{4}$, Leszek Bryniarski ${ }^{5}$ \\ ${ }^{1}$ Klinika Kardiologii Interwencyjnej, Instytut Kardiologii, Uniwersytet Jagielloński, Collegium Medicum, Kraków \\ ${ }^{2}$ Oddział Kardiologii, Szpital Specjalistyczny im. J. Dietla, Kraków \\ ${ }^{3}$ Klinika Chirurgii Urazowej i Ortopedii, 5. Wojskowy Szpital Kliniczny z Polikliniką, Kraków \\ ${ }^{4}$ II Klinika Kardiologii i Interwencji Sercowo-Naczyniowych, Instytut Kardiologii, Uniwersytet Jagielloński, Collegium Medicum, Kraków \\ 5I Klinika Kardiologii i Elektrokardiologii Interwencyjnej oraz Nadciśnienia Tętniczego, Instytut Kardiologii, Uniwersytet Jagielloński, \\ Collegium Medicum, Kraków
}

\section{Streszczenie}

Wstęp: Przewlekłe okluzje tętnic wieńcowych (CTO), definiowane jako przepływ TIMI 0 w naczyniu z czasem okluzji dłuższym niż 3 miesiące, stwierdza się u 16-50\% pacjentów z chorobą wieńcową, w dużych rejestrach jest to ok. 20\%. Nadal istnieje dysproporcja między dużą częstością występowania przewlekłych okluzji a liczbą przezskórnych udrożnień. Odpowiadać za to mogą wysokie techniczne wymagania zabiegów, wątpliwości kliniczne dotyczące korzyści z udrożnienia zamkniętej tętnicy 
i brak wiedzy o CTO. W wyspecjalizowanych centrach medycznych zajmujących się tematyką CTO skuteczność tych zabiegów wzrosła do 90\%. Według nieopublikowanych danych z Association of Cardiovascular Interventions of Polish Cardiac Society w czasie pierwszego półrocza roku 2014 spośród 601 procedur CTO w Polsce 54\% zakończyły się powodzeniem (z czego 50\% pacjentów miało przepływ TIMI 3 po zabiegu, a 4\% TIMI 2).

Cel: Celem pracy było określenie stanu wiedzy polskich kardiologów interwencyjnych na temat CTO.

Metody: Badanie zostało przeprowadzone wśród kardiologów interwencyjnych w czasie dwóch największych polskich warsztatów kardiologii inwazyjnej - New Frontiers in Interventional Cardiology (NFIC) w Krakowie między 27 a 30 listopada 2014 r. oraz XVIII Warsaw Course on Cardiovascular Interventions (WCCI) między 9 a 11 kwietnia 2014 r. W tym celu użyto własnego kwestionariusza w języku polskim składającego się w większości z zamkniętych pytań z 2-6 odpowiedziami wielokrotnego wyboru. Ankieta została podzielona na kilka części: do oceny ogólnej charakterystyki grupy, wiedzy o CTO, a także opinii na temat dostępu udowego i promieniowego w czasie przezskórnych interwencji wieńcowych (PCI). Do analizy statystycznej użyto programu STATISTICA 8 PL software (StatSoft Inc.).

Wyniki: W badaniu wzięło udział 113 lekarzy, głównie specjalistów kardiologii będących samodzielnymi operatorami. Średnia długość pracy lekarzy wyniosła 13 lat. Większość ankietowanych (58\%) miała specjalizację z kardiologii, natomiast 33\% była w trakcie specjalizacji. Najczęstszym miejscem pracy był nieakademicki oddział kardiologii z hemodynamiką, 73\% przebadanych zdeklarowała się jako pierwsi operatorzy. Deklarowana skuteczność udrożnień CTO wynosiła 63,5\%. Większość respondentów zgodziła się, że operatorzy zaangażowani w program udrożnień CTO powinni wykonywać co najmniej 30-50 zabiegów rocznie. Tylko 5\% operatorów podało, że wykonuje więcej niż 50 udrożnień CTO rocznie, a 29\%, że wykonuje więcej niż 30 zabiegów CTO rocznie. Liczba wykonywanych CTO rosła wraz ze stażem pracy i nie różniła się między lekarzami pracującymi w ośrodkach akademickich i nieakademickich. Średnia zadeklarowana skuteczność udrożnień CTO wyniosła $63,5 \%$, a wśród operatorów wykonujących więcej niż 30 zabiegów rocznie — 70\%. Jedynie $67 \%$ uważa, że przed rewaskularyzacją należy ocenić żywotności mięśnia sercowego, a preferowaną metodą jest echokardiograficzna próba dobutaminowa. Aż 78\% badanych twierdzi, że PCI w CTO nie powinna być wykonywana ad hoc po diagnostycznej angiografii, a 51,5\%, że u chorych z wielonaczyniową chorobą wieńcową angioplastyka zamkniętej tętnicy powinna być przeprowadzona jako pierwsza. Wielorzędowa spiralna tomografia komputerowa w kwalifikacji i planowaniu zabiegu udrożnienia wg 91\% lekarzy nie powinna być rutynowo wykonywana przed każdą procedurą, ale może być użyteczna w wybranych przypadkach.

Wnioski: Wiedza większości polskich kardiologów interwencyjnych na temat przewlekłych okluzji tętnic wieńcowych jest zgodna z aktualnymi opiniami i konsensusem EuroCTO Club, jednak nadal konieczna jest edukacja i promowanie wiedzy o CTO nie tylko wśród młodych, mniej doświadczonych operatorów, ale także wśród lekarzy z dużym stażem pracy.

Słowa kluczowe: przezskórne interwencje wieńcowe, przewlekłe okluzje tętnic wieńcowych, wiedza lekarzy

Kardiol Pol 2015; 73, 9: 722-729 